\title{
Consumption-Savings Trade-Off in the Allocation of Migrants' Remittances and Economic Growth: The Cases of Burkina Faso and Senegal
}

By Samuel Maxime Coly \& François Joseph Cabral

Abstract- The objective of this research is to assess the impact on growth of reallocating migrant remittances for savings/investment purposes. It focuses on two countries in the West African Economic and Monetary Union (WAEMU)' zone (Burkina Faso and Senegal). The methodological approach adopted is dynamic Computable General Equilibrium (CGE) modeling that integrates a procedure for reallocating remittances. Simulation results show that an increase in the propensity to save as a result of reallocation of remittances received by households for savings purposes leads to an increase in economic growth.

Keywords: remittances, consumption, savings, investment, economic growth, CGE model.

GJHSS-E Classification: JEL Code: F24, E21, E22, F43, C68

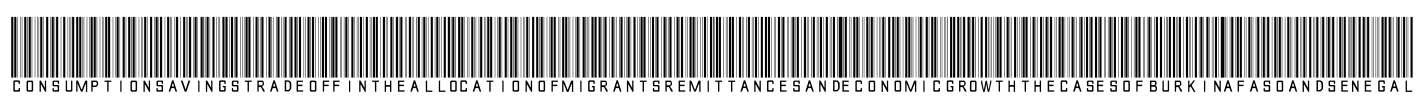

Strictly as per the compliance and regulations of:

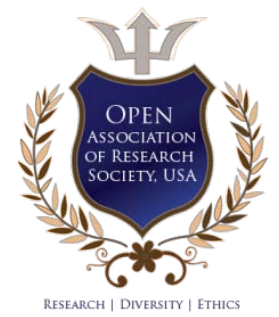

(C) 2020. Samuel Maxime Coly \& François Joseph Cabral. This is a research/review paper, distributed under the terms of the Creative Commons Attribution-Noncommercial 3.0 Unported License http://creativecommons.org/licenses/by-nc/3.0/), permitting all non-commercial use, distribution, and reproduction in any medium, provided the original work is properly cited. 


\title{
Consumption-Savings Trade-Off in the Allocation of Migrants' Remittances and Economic Growth: The Cases of Burkina Faso and Senegal
}

\author{
Samuel Maxime Coly ${ }^{\alpha} \&$ François Joseph Cabral ${ }^{\sigma}$
}

\begin{abstract}
The objective of this research is to assess the impact on growth of reallocating migrant remittances for savings/investment purposes. It focuses on two countries in the 'West African Economic and Monetary Union (WAEMU)' zone (Burkina Faso and Senegal). The methodological approach adopted is dynamic Computable General Equilibrium (CGE) modeling that integrates a procedure for reallocating remittances. Simulation results show that an increase in the propensity to save as a result of reallocation of remittances received by households for savings purposes leads to an increase in economic growth.
\end{abstract}

Keywords: remittances, consumption, savings, investment, economic growth, CGE model.

\section{InTRODUCTION}

( ver the last two decades, international migration has been one of the major challenges to economic development, in this case in developing countries (DCs). According to World Bank statistics, in 2015 the number of people living outside their country of birth reached approximately 243 million people with a growth rate of $238 \%$ compared to 1960 .

The increase in the stock of migrants worldwide has been accompanied by a more sustained increase in remittances from migrants around the world. Indeed, migrant remittances to developing countries are expected to be around US\$ 435 billion in 2014 and to reach US\$ 454 billion in 2015. Remittances registered in Sub-Saharan Africa are around \$38 billion in 2014 and are expected to reach around $\$ 41$ billion in 2015, i.e. about $7 \%$ of the remittances transiting through the world (World Bank, 2015).

According to BCEAO statistics, within the WAEMU, where remittances are the focus of special attention, the amount of remittances sent by migrant workers more than quadrupled between 2000 and 2013. Indeed, the flows recorded during this period increased

Author a: Doctor in Economics, Cheikh Anta Diop University of Dakar; Researcher at the Research Laboratory on Institutions and Growth (LINC). e-mails: samuelmaxime.coly@ucad.edu.sn,

samuelmaxime86@gmail.com

Author a: Professor of Economics, Cheikh Anta Diop University of Dakar, Faculty of Economics and Management, Department of Economics. Head of the Research Laboratory on Institutions and Growth (LIN).e-mails: françoisjoseph.cabral@ucad.edu.sn,

joecabral7@gmail.com from CFAF 323.1 billion in 2000 to CFAF 1902.5 billion in 2013 , i.e. an increase of $489 \%$. Senegal, with $\$ 1.6$ billion of remittances declared in 2015, is the 3rd country behind Nigeria and Ghana among the 10 main countries in Sub-Saharan Africa receiving remittances from migrants (Word Bank, Factbook 2016); which gives it a leading position within the 'West African Economic and Monetary Union (WAEMU)' zone. Alongside Senegal, Burkina Faso is the leading migrant-sending country within the 'West African Economic and Monetary Union (WAEMU)' (27\% of migrants in this zone in 2015 are from Burkina Faso according to UN statistics, DESA, 2015).

The stakes of the migratory phenomenon are as much of a micro-economic as of a macro-economic nature. While from a microeconomic point of view a consensus seems to be emerging that the decision to send remittances would be motivated by personal interest (acquisition of possessions in the country of origin, preservation of respect, etc.), altruism (concern to help) or a family strategy in the face of risk in the sense that the decision to migrate is taken at the family level (Stark and Levhari 1982; Stark 1991; Coate and Ravaillon 1993; Taylor and Wyatt 1996; Agunias 2006) and that these remittances would thus improve the wellbeing of the receiving households, at the macroeconomic level, remittances are believed to result from a combination of macroeconomic factors in the receiving and sending countries (Lucas and Stark 1985; Agarwal and Horowitz 2002; Rapoport and Docquier 2005; Rao and Hassan 2012; Coorey 2012) ${ }^{1}$. Also, the perceved role of remittances remains a source of divergence between streams: for the former, migration

\footnotetext{
${ }^{1}$ When, for example, the economic situation in the country of origin deteriorates, funds transfers increase because of the altruism that motivates the migrant. On the other hand, in cases where selfish behavior predominates and the migrant's well-being depends largely on maximizing his or her income, funds transfers decrease because of the lower profitability of the funds invested (Lucas and Stark, 1985; Agarwal and Horowitz, 2002). Moreover, funds transfers represent a significant source of foreign exchange for finances in countries of origin; they can also improve aggregate factor productivity and would be an externality and a source of innovation (Rao and Hassan, 2012; Coorey, 2012).
} 
and remittances represent a strategy to increase incomes, invest in new activities and overcome income and production risks; for the latter, remittances are used mainly for consumption, and less for productive activities (Chami et al., 2005), and are therefore inflationary (Taylor, 1999).

Consequently, one might ask the question: what would be the impact of remittances on development and economic growth in the countries of origin when these funds are used for investment purposes?

The consumption and savings behavior of agents has been the subject of theoretical debates about its impact on economic growth. Three theories are most often presented in the economic literature.

The first is the neoclassical view (proponents of prior savings), which goes back to the neoclassical growth model (Harrod, 1939; Domar, 1946 and Solow, 1956). These growth models support the ideas that increased accumulation of savings increases the rate of investment and thus stimulates economic growth. These models are supported by empirical work that has found a causal relationship ranging from growth in domestic savings to economic growth (Sheggu, 2009; Lean and Song, 2009).

The alternative point of view, largely drawn from Keynes (1936) model with the General Theory but also from consumption theories, is the tradition of residual savings. These theories put forward a sense of reverse causality in contrast to the neoclassical view. According to Keynes, the direction of causality is reversed in that it is economic growth that stimulates savings. In other words, economic growth is the origin of savings. Indeed, it is from income growth that consumption growth results; the savings supplement being residual. This thesis has made it possible to justify in developing countries interventionist public policies in the regulation of the economic situation, but also the dominant weight of public enterprises in the industrial structure of the economy, with a view to generating, via the multiplier effect, the growth of jobs and distributed income necessary for the formation of savings. To this end, Saltz (1999), studying the causal relationship between savings and growth in Third World countries, finds that higher growth accelerates the growth of the savings rate.

Alongside these two main currents of thought, there is an intermediate view which maintains that the link between savings and economic growth is made through the consumption-savings trade-off. This vision is the source of observations that largely contradict the implications of the Keynesian model and lead to the formulation of life-cycle (Modigliani and Brumberg, 1954; Ando and Modigliani, 1963) and permanent income (Milton Friedman, 1957) models. Causal relationships can be identified starting from the theories incorporating the importance of growth in per capita income, permanent income or wealth in the savings functions (Friedman, 1957). Consumption and life-cycle theories imply that individuals choose their levels of consumption (and thus also savings) according to current and future income levels. Mohan (2006), examining the relationship between savings and economic growth in high-, middle- and low-income countries found that the causality runs from economic growth to savings. However, the results indicate that in countries with a forced savings policy such as Singapore, the causality is from savings to economic growth.

The lack of a rigorous or even precise understanding of the transmission channels of remittances on economic activity makes the results regarding the impact of these funds on growth in SubSaharan Africa ambiguous (Singh et al., 2010). And, in the case of 'West African Economic and Monetary Union (WAEMU)' member countries in general, in Burkina Faso and Senegal in particular, there are limited studies explaining the phenomenon in a macroeconomic framework.

The objective of this work is to assess the impact of reallocating transfers to consumption needs for savings purposes on economic growth in Burkina Faso and Senegal .

This research is based on the hypothesis that a reallocation of remittances to increased savings would allow for a higher level of investment and ultimately increase economic growth.

The remainder of this work is structured as follows: Section 2 provides a brief overview of the importance and uses of remittances; Section 3 presents a review of the empirical literature on the use of migrant remittances; Section 4 outlines the methodology; and Section 5 discusses the main findings before concluding and drawing some policy implications.

\section{il. A Growing Weight of Remittance- Related Income and a Different Allocation in Different Countries}

Remittances have increased considerably, surpassing even official development assistance and foreign direct investment flows. Burkina Faso and Senegal are two interesting countries in the WAEMU zone in terms of their migration profile and remittances received. Indeed, remittances have increased from $\$ 84$ million in 2007 to $\$ 120$ million in 2010 for Burkina Faso and from $\$ 1192$ million to $\$ 1478$ million over the same period for Senegal (Figure 1).

In the cases of Burkina Faso and Senegal, a significant portion of remittances is generally spent on everyday consumer goods, while a smaller portion is invested or saved. 


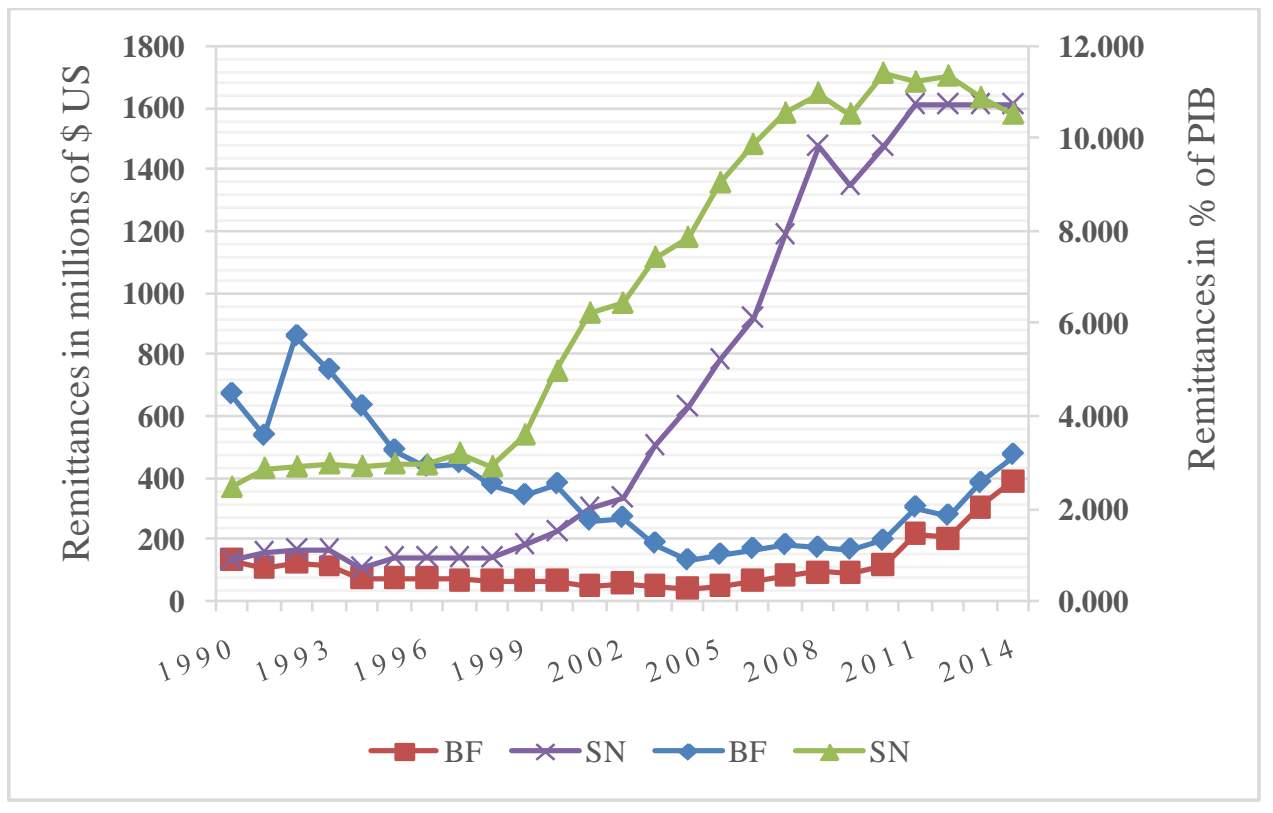

Source: Author based on World Bank data.

Figure 1: Evaluation of remittances in millions of US\$ and as a \% of GDP

According to the results of the survey on remittances conducted by the BCEAO in 2011 (table 1), the economic reasons for migrants' remittances are mainly related to support for current consumption, in Senegal nearly $70 \%$ while less than $10 \%$ of these resources are devoted to investment and savings. In
Burkina Faso, the various items for which remittances are allocated are current consumption (37\%), property investment (25\%), other investments (16\%), education and health $(17.2 \%)$, family events $(1.7 \%)$, savings $(1.5 \%)^{2}$ and others $(0.3 \%)$.

Table1: Use of remittances

\begin{tabular}{ccc}
\hline Economis motives & Burkina Faso & Senegal \\
\hline \hline Current consumption & 37,3 & 69,8 \\
Health & 2,2 & 1,3 \\
Education & 15 & 6,1 \\
Family events & 1,7 & 8,2 \\
Property investments & 25,7 & 7,6 \\
Other investissements & 16,3 & 1,2 \\
Savings, tontine & 1,5 & 0,5 \\
Others & 0,3 & 5,3 \\
Total & 100 & 100 \\
\hline
\end{tabular}

Source: BCEAO Survey Results, 2011

Another way to assess the use of remittances received within these two economies is to examine the status of the receivers (Figure 2). In Burkina Faso, the groups most represented among remittance recipients are pupils and students (31.3\%) and the inactive $(16.4 \%)$, which reflects a high proportion of the use of remittances for current expenditure purposes in Burkina Faso. The self-employed and employees are poorly represented. In Senegal, the group that stands out is that of the inactive, who receive $30.9 \%$ of the funds, while pupils and students receive only $6.1 \%$ of the amounts transferred. Nearly $33 \%$ of remittances are allocated to the self-employed; $10.9 \%$ to employees and $4.4 \%$ to artisans.

2 The data do not allow us to distinguish informal savings collected by tontines from other more formal forms of savings. Frank Wittmann and Patrick Mbonyinshuti (2006) pointed out that the welfare gains associated with informal savings collected by tontines do not emerge because they do not finance much production, but rather finance more the consumption of durable goods, which are import intensive. 


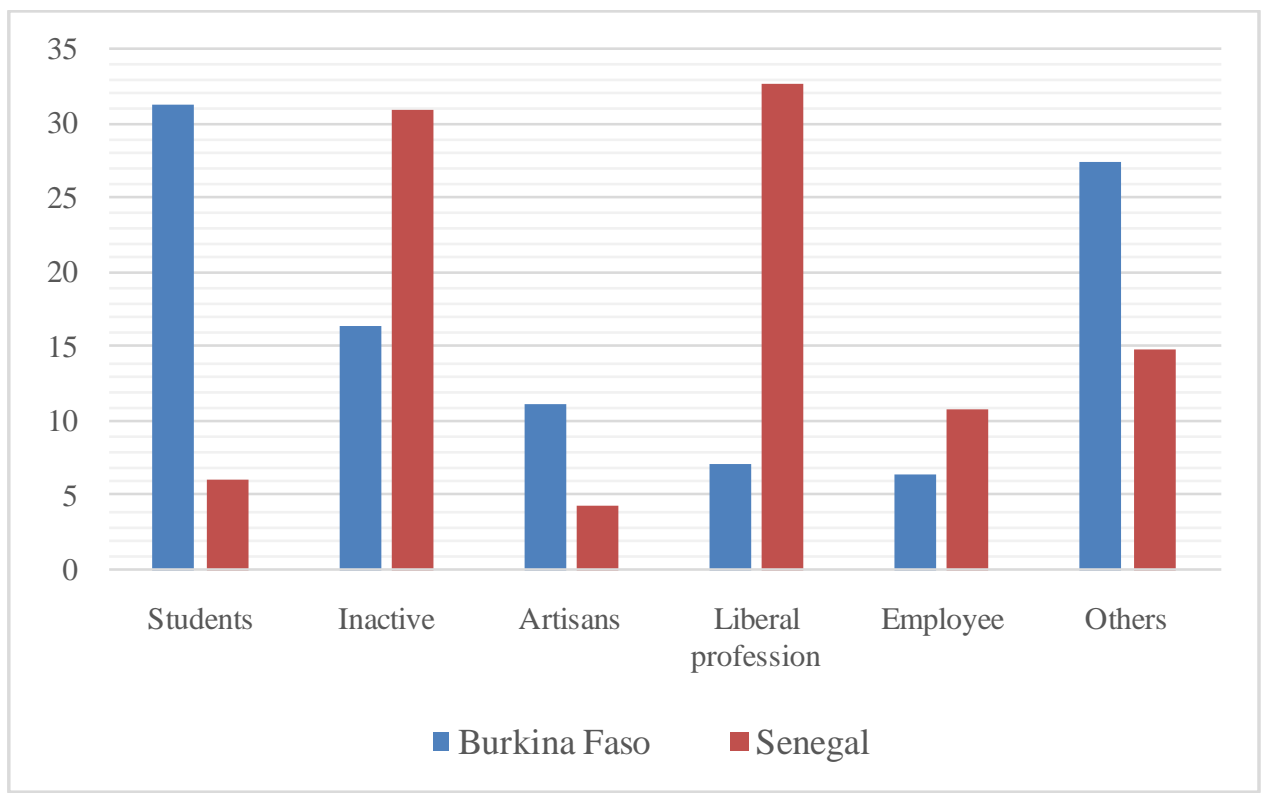

Source: BCEAO Suney Results, 2011

Figure 2: Repartition of remittances according to the status of the receiver

\section{Use of Remittances: Synthesis of SOME EMPIRICAL WORK}

The issue of the use of remittances, whether for consumption or investment purposes, and their implications for recipient economies has been the subject of several empirical studies. Indeed, the economic impact of remittances depends, to a large extent, on their final uses: financing current consumption or savings/investment. In theory, remittances can change household spending patterns of various kinds, depending on how these financial flows are accounted for by recipient households (Adams and Cuecuecha, 2010; Adams and Cuecuecha, 2013).

For example, Maimbo and Ratha (2005) found that in some regions of Sub-Saharan Africa, almost $80 \%$ of remittances are allocated to consumption. The Multilateral Investment Fund of the Inter-American Development Bank (2004) found that consumption accounted for $60-80 \%$ of the use of remittances in a sample of five Latin American countries. Indeed, remittances from migrants smooth consumption by acting as an insurance mechanism against adverse shocks (Kannan and Hari, 2002; Lucas and Stark, 1985; Yang and Choi, 2007). In this regard, Chami, Fullenkamp and Jahjah (2005) find that the means by which remittances are typically invested (in housing, land and jewellery) are "non-productive" for the economy as a whole. In the case of China, Zhu et al (2012) using data from 1,498 households in Anhui and Jiangsu, find evidence that remittances were mainly used for consumption purposes and not for investment. On a large sample of rural households in three provinces surveyed in 2001 and 2004, Zhu et al (2014) also find that the marginal propensity to consume remittances is close to unity.

On the other hand, much more optimistic authors argue that remittances are much more correlated with investment than with consumption. Indeed, remittances could enhance investment by minimizing consumption volatility, leading to a stable macroeconomic environment conducive to investment activities (Singh et al., 2009). For example, studies have found that households receiving remittances have shown varying patterns of consumption and investment in certain products compared to those not receiving remittances. Osili (2004), for example, using matched data between Nigeria (origin country) and the United States (destination country), finds that a 10 per cent increase in migrants' income increases the probability of investing in housing by 3 percentage points in the origin country. In the Philippines, Yang (2008) shows that remittances are positively correlated with investment in human capital and investment in capital-intensive family businesses. According to these authors, remittancereceiving households spend more at the margin on investment goods because they treat their transfer income as transitory (rather than permanent) income and the marginal propensity to invest in transitory income is higher than for other sources of income. Adams et al, (2013) found similar results in Ghana.

\section{Methodology}

In several countries computable general equilibrium (CGE) models are widely used to analyse the effects of policy changes and/or shocks. They apply to the period of time it takes an economy to move from one equilibrium to another in response to a change in 
policy or a shock. For this purpose, a recursive-dynamic computable general equilibrium (CGE) model is used in this study. A dynamic structure makes it possible to reflect the investment process more accurately and thus to provide further insights into the effects of a reallocation of remittances on growth in this study.

\section{a) Model specification}

The dynamic model described below was developed from the Exter-DS dynamic model by Annabi, Cockburn and Decaluwé (2004). A number of features were added to the Exter-DS model for this study: a government budget block; the inclusion of public capital; an export demand function; endogenous total factor productivity growth; and a household savings function that distinguishes between disposable income (excluding transfers) and a part that incorporates transfers for savings. The new characteristics, such as endogenized total factor productivity (TFP), are inspired by the approach of Lucas $(1988)^{3}$, Barro $(1990)^{4}$ and Romer $(1986)^{5}$, while the new functional form of household savings takes into account the specific needs of the study.

However, they require a number of adjustments to the existing equations and the addition of new equations that will be presented in this section.

The total stock of public capital creates a positive externality for each activity that affects the total productivity of the sector. TFP is also affected by the distribution of public investment between human capital, research and development and infrastructure, which depends on government decisions (1). Consequently, TFP is determined endogenously and is assumed to be a function of human capital $(\mathrm{KH})$, research and development (R\&D), infrastructure $(\mathrm{PI})$ and the ratio between total public capital and sectoral private capital (KDpubG/KDpriv):

$A_{t r}^{t}=\overline{A_{t r}^{t}}\left[\left(K H_{t r}^{t}\right)^{\varepsilon_{k}} *\left(R D_{t r}^{t}\right)^{\varepsilon_{r}} *\left(I P_{t r}^{t}\right)^{\varepsilon_{i}} *\left(\frac{K D p u b G^{t}}{K D p r i v_{t r}^{t}}\right)^{\varepsilon_{k}}\right]$

Household income comes from three sources: labour income, return on capital and transfers received from other agents:

3 For Lucas (1988), the "self-sustaining" character of growth is possible, thanks to the human capital that makes technological progress endogenous. Moreover, technical progress and innovation (as measured by total factor productivity) are achieved by researchers or engineers, who are also the product of investment in human capital.

${ }^{4}$ According to Barro (1990), economic growth results from investment in public infrastructure, which is a growth factor that generates increasing returns over the long term because of the positive externalities it generates for firms. It is therefore public capital that explains growth.

${ }^{5}$ According to Romer (1986), research and development is the main driver of economic growth. According to this author, economic growth is the result of innovative activity by agents who hope to benefit from it, because the fundamental incentive for innovation is linked to the temporary monopoly it confers on producers of new goods.

$$
Y H_{h, t}=Y H L_{h, t}+Y H K_{h, t}+Y H T R_{h, t}
$$

Each type of household receives a fixed share of the income from each type of work:

$$
Y H L_{h, l}=\sum \lambda_{h, l}^{W L}\left[W_{l, t} \sum_{j} L D_{l, j, t}\right]
$$

Total capital income is distributed among agents, including capitalist households, in fixed proportions:

$$
Y H K_{h, t}=\sum_{k}^{R K} \lambda_{h, k}^{R K}\left(R_{k, t} \sum_{j} K D_{k, j, t}\right)
$$

Transfer income is obtained by aggregating all transfers received (transfers from domestic agents and transfers from the rest of the world):

$$
Y H T R_{h, t}=\sum_{\text {agd }} T R_{h, \text { agd }, t}+T R_{h, r o w, t}
$$

As a result, remittance income from domestic agents differs from remittance income from the rest of the world (migrant remittances):

$$
\begin{aligned}
\operatorname{YHRRN}_{h, t} & =\sum_{\text {agd }} T R_{h, \text { agd }, t} \\
Y H T R W & =T R_{h, \text { row }, t}
\end{aligned}
$$

However, it should be noted, as Taylor (1999) pointed out, that it is impossible to differentiate exactly how remittances have been used, relative to other household income, because of the identical form they take. This is one of the main limitations of this study.

Household disposable income is equal to the difference between income, direct taxes and transfers to other state institutions:

$$
\mathrm{YDH}_{h, t}=\mathrm{YH}_{h, t}-\mathrm{TDH}_{h, t}-\mathrm{TR}_{g v t, h, t}
$$

The real consumption expenditure of households is equal to the difference between disposable income, savings and transfers to other agents:

$$
C T H_{h, t}=Y D H_{h, t}-S H_{h, t}-\sum_{a g n g} T R_{a g n g, h, t}
$$

Household savings is a linear function of disposable income (excluding migrants' remittances) and the part of remittances used for savings/investment:

$$
\begin{aligned}
S H_{h, t}= & P I X C O N_{t}^{\eta} \operatorname{sh} 0_{h, t}+\operatorname{sh} 1_{h, t}\left[Y H L_{h, t}+Y H K_{h, t}+Y H T R N_{h, t}\right] \\
& +\operatorname{sh} 12_{h, t} Y H T R W_{h, t}-s h 1_{h, t}\left[T D H_{h, t}+T R_{g v t, h, t}\right]
\end{aligned}
$$

The process of capital accumulation is modelled endogenously. The sectoral private capital stock at the end of the period is equal to the stock of the previous period minus the depreciation of capital in the period plus the volume of capital accumulated during the period. The rate of sectoral capital accumulation in 
period $t$ is an increasing function of the cost-benefit ratio of capital in the same period, at a decreasing rate.

Population growth is implemented exogenously in the model on the basis of separately calculated growth projections. It is assumed that a growing population generates a higher level of consumer demand and thus increases the level of surplus income for household consumption. It is also assumed that the marginal rate of commodity consumption remains unchanged, implying that new consumers have the same preferences as existing consumers.

The supply of labor is equal to the sum of the demand for labor. Transfers, labor, public consumption and the minimum level of consumption are also determined exogenously between periods.

The model comprises three main macroeconomic accounts: the current account, the general government balance and the savings and investment account. In order to ensure that the various macroeconomic accounts are in balance, it is necessary to specify a set of "macro closure" rules that provide a mechanism for assuming that adjustment takes place.

The ratio of the current account to GDP is assumed to be fixed. The exchange rate and inventories are fixed, as is the propensity of institutions to save. Government expenditure is also assumed to be fixed in real terms in the first period. However, they increase at the same rate as the population increases. Government savings, transfers and labor supply follow the same pattern. Consequently, these different variables are fixed in the first period.

While government and current account closures can be chosen based on current government policies, the choice of a savings-investment closure is less obvious.

Since Burkina Faso and Senegal cannot borrow without limits, mainly because of the convergence criteria established by the West African Economic and Monetary Union (WAEMU), the long-term savingsinvestment nexus is characterized by exogenous savings without a feedback reaction from investment behavior. Consequently, the model adopts a savingsdriven closure, in which the savings rates of domestic institutions are fixed and investment adjusts passively to ensure an equal level of equilibrium between savings and investment expenditure.

b) Data

The CGE model thus described is calibrated according to a SAM for each country in the study. For the Senegalese economy, the calibration is based on a 2014 SAM constructed by the Agence Nationale de la Statistique et de la Démographie (ANSD) and the Laboratoire de Recherches sur les Institutions et la Croissance (LINC) using data from an input-output table (IOT) and a household survey conducted in 2011 (ANSD). For the Burkinabe economy, the adjusted SAM of Décaluwé in 2008 updated for the year 2014 with data from the World Bank, BCEAO and INSD Burkina Faso was used.

In both SAMs, production activities comprise $13^{5}$ branches of activity derived from the disaggregation of agriculture, industry and market services; non-market services are integrated in its aggregate form. They take into account the 4 standard institutional units (Households, Firms, Government and Rest of the World). They also integrate two types of capital factor (private capital and public capital). The labor market is segmented into two categories: skilled and unskilled labor.

\section{Simulation and Results}

\section{a) Justification of the simulation}

The simulated share refers to the South African ${ }^{6}$ economic model where in 2017 the propensity to save was $26 \%$ of household disposable income (OECD statistics). We thus simulate a $30 \%$ increase in the propensity to save migrant remittances (i.e. $4 \%$ more than the propensity to save of the South African model; this is to amplify the impact and bring us closer to this model in advance).

\section{b) Results of the simulations}

In order to understand the impact on economic growth of a reallocation of remittances, several transmission channels (direct and/or indirect) can be visited.

The simulation results show that an increase in the propensity to save remittances increases the level of overall household savings compared to the BAU (Business As Usual) or reference situation (Figure 3). This increase in the level of savings translates into an increase in investment, with a much higher level in Burkina Faso than in Senegal, where the upward variation is very negligible although it does exist (Figure 4). Indeed, analysis of the structure of remittance use from the BCEA survey conducted in 2011 reveals much higher proportions of investment of remittances received among Burkinabe recipients (about 42\%) than among Senegalese recipients (about 9\%) for whom a considerable share of these funds is destined for current consumption (nearly 70\%). Household survey data from the African Migration Project concluded that a significant portion of international remittances was spent on land purchases, housing construction, business, farm improvements, agricultural equipment and other

\footnotetext{
${ }^{5}$ Cereal crops, Other food crops, Cotton growing, Other cash crops, Cattle breeding, Fishing and aquaculture, Mining and quarrying, Manufacturing, Construction, Post and telecommunications, Hotels and restaurants, Other market services, Non-market services.

${ }^{6}$ The reference to the South African economic model is justified by the fact that South Africa is in many ways an African success story.
} 
investments. Investments in these areas, as a proportion of total remittances received, accounted for 36.4 per cent in Burkina Faso while they accounted for only 15.5 per cent in Senegal.

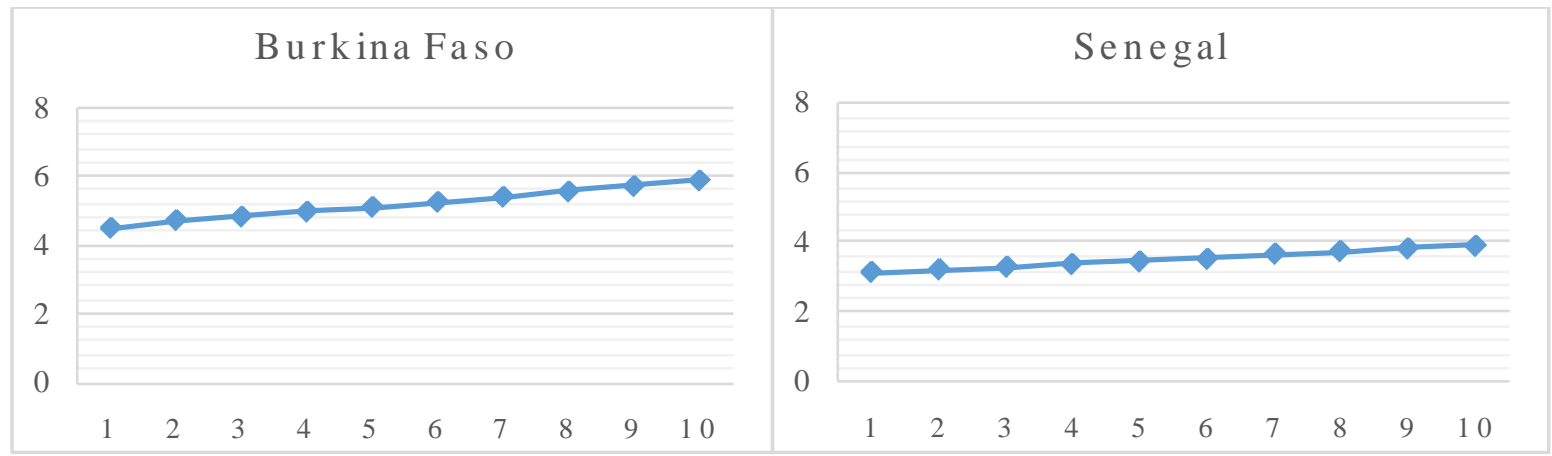

Figure 3: Evolution of household saving s compared to the BAU scenario

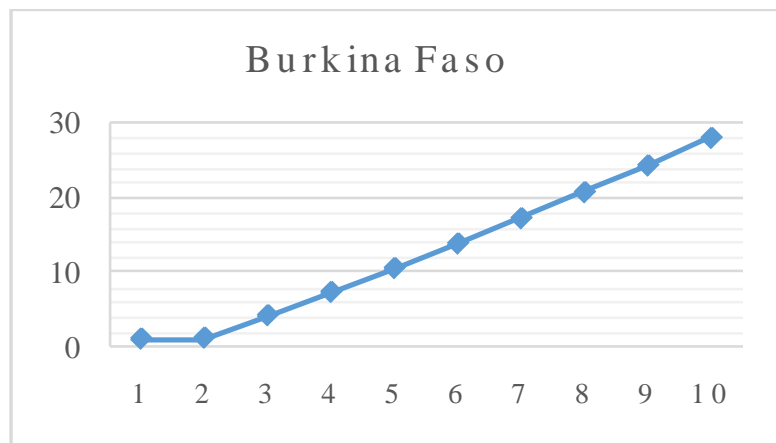

Figure 4: Evolution of total investment compared to the BAU scenario

The increase in the level of investment, driven by the increased propensity of households to save as a result of a reallocation of funds received by the latter, leads to an increase in GDP growth at factor cost in proportions similar to those of investment (Figure 5). The main implication of these results is that the increased accumulation of savings stimulates GDP growth through increased investment. Thus, when GDP

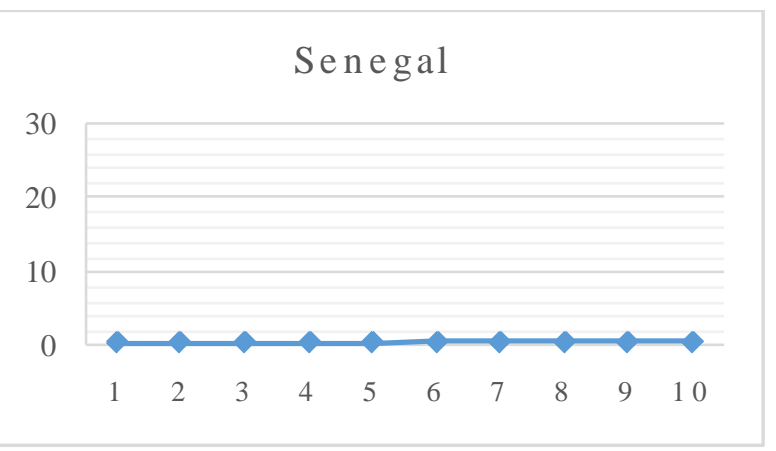

Source: Author, results of the simulation

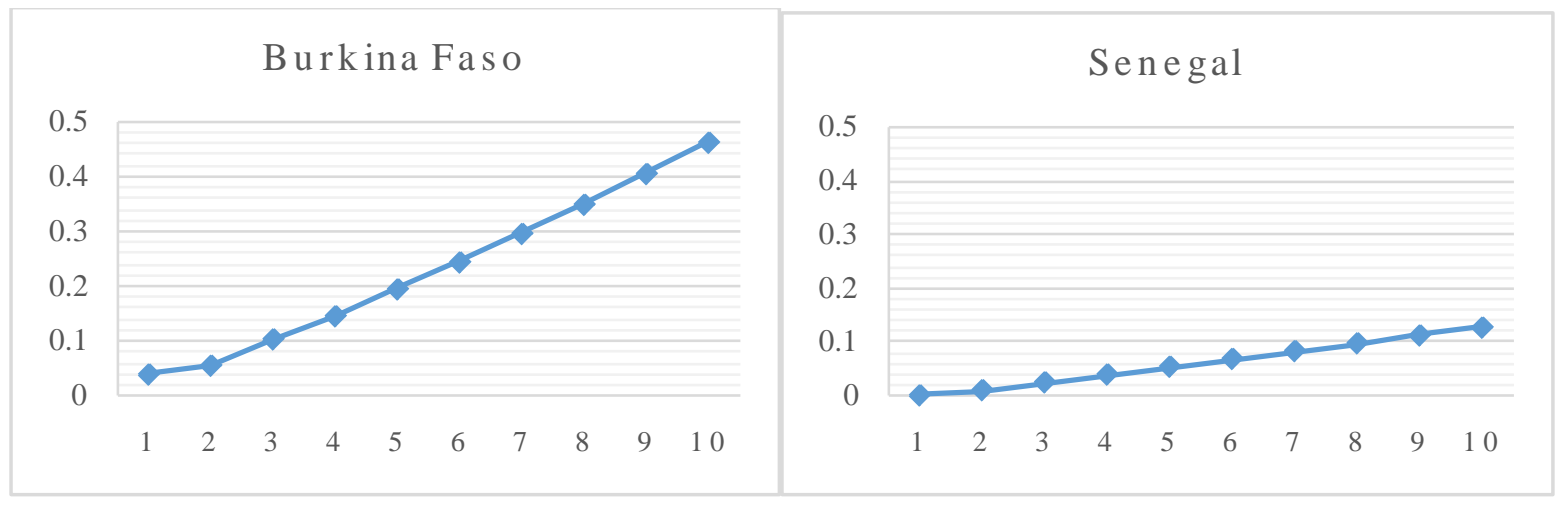

Figure 5: Evolution of GDP growth at factor cost compared to the BAU scenario 


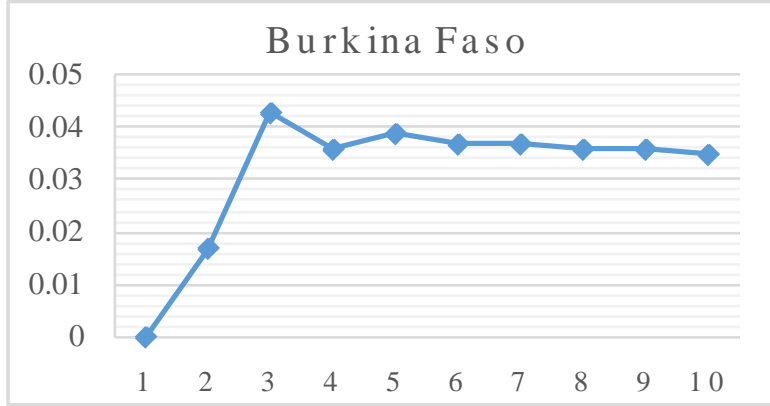

$\begin{array}{llllllllll}1 & 2 & 3 & 4 & 5 & 6 & 7 & 8 & 9 & 1\end{array}$

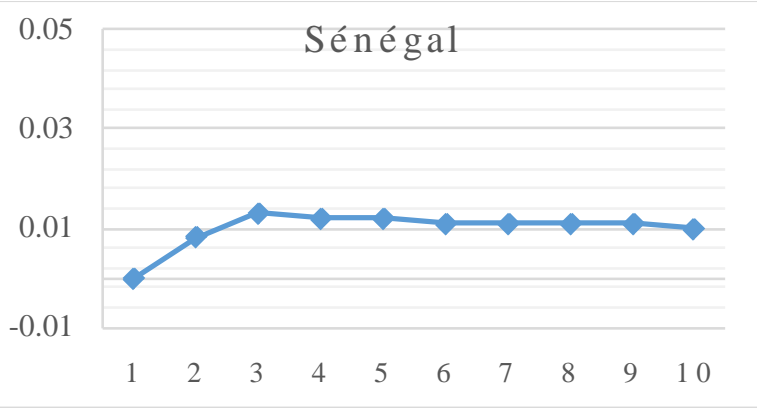

Source: Author, results of the simulation

Figure 6: Evolution of GDP growth rate at market prices compared to the BAU scenario

Looking at sectoral effects, changes in value added indicate that the industrial sector stands out from the pack; this can be attributed to the activities of small enterprises in which remittance-receiving households would be active. The value added of the agriculture and market services sectors show a negative variation at first and a positive variation over the rest of the period, while the contribution of the non-market services sector remains relatively stable (compared to the BAU).

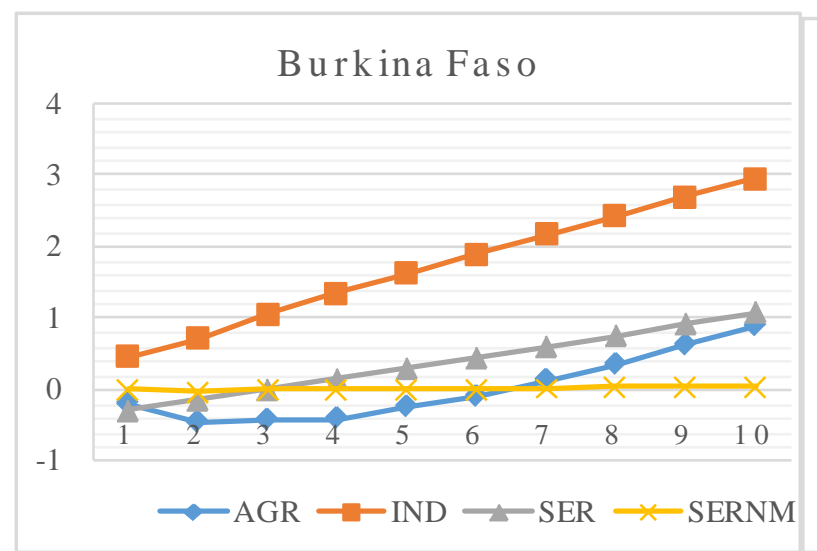

Figure 7: Evolution of sectorial VA in \% compared to BAU

\section{Conclusion}

In this research we analyze the impact on economic growth in Burkina Faso and Senegal of reallocating migrant remittances to consumption needs for investment purposes. The research is based on a dynamic computable general equilibrium (CGE) model to which we have incorporated features to take into account the process of reallocation of remittances.

Simulation results over a 10-year period show that a $30 \%$ increase in the propensity to save remittances increases GDP growth in Burkina Faso and Senegal. Indeed, an increase in household savings leads to an increase in investment which drains more economic growth. The industrial sector is the branch of activity that contributes most to growth. Its added value is increasing compared to the reference situation more than the other sectors with, in particular, an increased and positive evolution over the entire period. This could be due to the activities of small enterprises in which

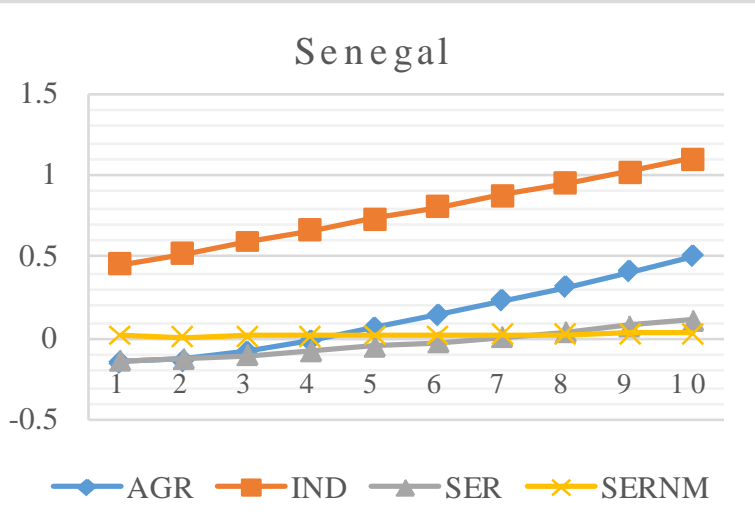

Source: Author, results of the simulation

households are active, provided that they receive investment-oriented transfers.

The main economic implications suggested by these results are that remittances represent an important channel of external financing for the economy as a whole. The use of remittances for savings/investment purposes would improve economic growth, hence the need for incentives to increase savings and small businesses, which in turn will increase investment in the long run.

\section{References Références Referencias}

1. Adams, R. H., and Cuecuecha, A., 2010, "Remittances, Household Expenditure and Investment in Guatemala". World Development, Vol.38 No.11, pp.1626-1641.

2. Adams, R. H., and Cuecuecha, A., 2013, "The Impact of Remittances on Investment and Poverty in Ghana", World Development, Vol. 50, pp. 24-40. 
3. Agarwal, R., and Horowitz, A.W., 2002, "Are International Remittances Altruism or Insurance? Evidence from Guyana Using Multiple-Migrant Households", World Development, Vol. 30, pp. 2033-44.

4. Agunias, D. R., 2006, "Remittances and Development: Trends, Impacts, and Policy Options. A Review of the Literature", Migration Policy Institute.

5. Ando, A. and Modigliani, F., 1963, "The 'life-cycle' hypothesis of saving: aggregate implications and tests", American Economic Review, Vol. 53, No.1, pp.55-84.

6. Annabi, N., Cockburn, J., and Decaluwé, B., 2004, "A sequential dynamic CGE model for poverty analysis", http://www.cirpee.org .

7. Barro, R.J., 1990, "Government Spending in a Simple Model of Endogenous Growth", Journal of Political Economy, Vol. 98, No. 5, part II, S103-S125, October.

8. Brumberg, R. and Modigliani, F., 1954, "Utility Analysis and the Consumption Function: An Interpretation of Cross-Section Data", In Post Keynesian Economics, ed. Kenneth K. Kurihara, pp. 88-436. New Brunswick: Rutgers University Press

9. Chami, R., Fullenkamp, C., and Jahjah, S., 2005, "Are Immigrant Remittance Flows a Source of Capital for Development?" IMF Staff Papers, Vol. 52, No. 1, pp. 55-81.

10. Coate, S. and Ravaillon, M., 1993, "Reciprocity Without Commitment, Characterization and Performance of Informal Insurance Arrangements", Journal of Development Economics, Vol. 40, pp. 1-24.

11. Coorey, A., 2012, "The Impact of Migrant Remittances on Economic Growth: Evidence from South Asia", Review of International Economics, Vol. 20 No.5, pp. 985-998.

12. Domar, E., 1946, "Capital Expansion, Rate of Profit and Employment", Econometrica, Vol.14 No. 2, pp. 137-147.

13. Friedman, M., 1957, "A Theory of the Consumption Function", Princeton and Oxford: Princeton University Press.

14. Harrod, R. F., 1939, "An Essay in Dynamic Theory", The Economic Journal Vol.49 No. 193 pp. 14-33, JSTOR 2225181.

15. Kannan, K.P. and Hari, K.S., 2002, "Kerala's Gulf connection: remittances and their macroeconomic impact", Saint Joseph Press (Inde).

16. Keynes, J.M., 1936, "The General Theory of Employment, Interest and Money", London, Mac Millan, Traduction francaise J.de Largentaye, Payot, (1985).

17. Lean, H. H. and Song, Y., 2009, "The Domestic Savings and Economic Growth Relationship in
China", Journal of Chinese economic and Foreign Trade Studies, Vol. 2, No.1, pp. 5-17.

18. Lucas, R., 1988, "On the Mechanisms of Economic Growth", Journal of Monetary Economics, Vol. 22, No.1, pp. 3-42.

19. Lucas, R. E. B., and Stark, O., 1985, "Motivations to Remit: Evidence from Botswana", Journal of Politica Economy, Vol. 93 No.5, pp. 901-18.

20. Maimbo, S. and Ratha, D., 2005, "Remittances: development impacts and future prospects", Banque mondiale.

21. Mohan, R., 2006, "Causal Relationship between Savings and Economic Growth in Countries with Different Income levels", Economics Bulletin, Vol. 5, No. 3, pp.1-12.

22. Multilateral Investment Fund, 2004, "Sending Money Home: Remittance to Latin America and the Caribbean", Washington: Inter-American Development Bank.

23. Osili, U. O., 2004, "Migrants and Housing Investments: Theory and Evidence from Nigeria", Economic Development and Cultural Change Vol. 52, No.4, pp. 821-49.

24. Rao, B. and Hassan, G., 2012, "Are Direct and Indirect Growth Effects of Remittances Significant?" The World Economy, Vol. 35, pp. 351-377.

25. Rapoport, H. and Docquier, F., 2005, "The Economics of Migrants' Remittances", IZA Discussion Paper No. 1531.

26. Romer, P.M., 1986, "Increasing Returns and LongRun Growth", Journal of Political Economy, Vol. 94, No. 5, pp. 1002-1037.

27. Saltz, I. S., 1999, "An Examination of the Causal Relationship between Savings and Growth in the Third World", Journal of Economics and Finance, Vol.23 no.1, pp. 90-98.

28. Sheggu, D., 2009, "Causal Relationship between Growth and Real Gross Domestic Savings: Evidence from Ethiopia".

29. Singh, R. J., Haacker, M., Lee, K.W. and Goff, M. L., 2010, "Determinants and Macroeconomic Impact of Remittances in Sub-Saharan Africa", Journal of African Economies, Vol. 20, No.2, pp. 312-340. 25.

30. Singh, R. J., Haacker, M. and Lee, K., 2009, "Determinants and macroeconomic impact of remittances in Sub-Saharan Africa", IMF working paper WP/09/216.

31. Solow, R., 1956, "A Contribution to the Theory of Economic Growth", Quaterly Journal.

32. Stark, O. and Levhari, D., 1982, "On Migration and Risk in LDCs", Economic Development and Cultural Change, Vol.31, No.1, pp. 191-196.

33. Stark, O., 1991, "La migration dans les pays en développement: les risques, les transferts et la famille", Finances et Développement, Vol. 28 No.4, pp.39-41. 
34. Taylor, E. J., 1999, "The New Economics of Labour Migration and the Role of Remittances in the Migration Process", International Migration Vol.37, No.1, pp. 63-88.

35. Taylor, J.E. and Wyatt, T.J., 1996, "The Shadow Value of Migrant Remittances, Income and Inequality in a Household-Farm Economy", Journal of Development Studies, Vol.32, No.6, pp. 899-912.

36. Wittmann, F. and Mbonyinshuti, P., 2006, "L'Afrique dans la Globalisation économique", Arbeitspapiere / Working Papers Numéro 62, Department of Anthropology and African Studies.

37. Yang, D., and Choi, H.-J., 2007, "Are remittances insurance? Evidence from rainfall shocks in the Philippines", World Bank Economic Review, Vol. 21, No. 2.

38. Yang, D., 2008, "International migration, remittances and household investment: Evidence from Philippine migrants' exchange rate shocks", The Economic Journal, Vol. 118, pp. 591-630.

39. Zhu, Y., Wu, Z., Peng, L., and Sheng, L., 2014 , "Where did all the remittances go? Understanding the impact of remittances on consumption patterns in rural China", Applied Economics, Vol. 46, No.12, pp.1312-1322.

40. Zhu, Y., Wu, Z., Wang, M., Du, Y., and Cai, F., 2012, "Do migrants really save more? Understanding the impact of remittances on savings in rural China", Journal of Development Studies, Vol. 48, No.5, pp.654-672. 